\title{
Protective Activity of A $\beta$ on Cell Cultures (PC12 and THP-1 after Differentiation) Preincubated with Lipopolysaccharide (LPS)
}

\author{
Benita Wiatrak $^{1,2}$ (D) Katarzyna Balon $^{2}$ (D) \\ Received: 3 August 2020 / Accepted: 4 November 2020 / Published online: 14 November 2020 \\ (C) The Author(s) 2020
}

\begin{abstract}
Amyloid- $\beta$ (A $\beta$ ), the influence of which is considered the pathomechanism of Alzheimer's disease, is also present in healthy people. The microbiome's impact is also taken into account, where bacterial lipopolysaccharide (LPS) activates inflammatory processes and stimulates microglia via TLRs. Molecules of bacterial origin can co-create senile plaques with A $\beta$. This study evaluated the activity of physiological A $\beta$ concentrations on neuronal and microglial cells after preincubation with LPS. Two cell lines were used in the study: PC12 cells differentiated with NGF and THP-1 cells differentiated with phorbol 12-myristate 13acetate (PMA). Cells were incubated with LPS at concentrations of $1-100 \mu \mathrm{M}$ for $24 \mathrm{~h}$ and then with $\mathrm{A} \beta_{25-35}$ at a concentration of $0.001 \mu \mathrm{M}$ or $1.0 \mu \mathrm{M}$ for another $24 \mathrm{~h}$. The viability of the culture and free oxygen radicals and the number of DNA strand breaks in both cell lines were evaluated. Additionally, for PC12 cells, neural features were assessed. Stimulation of repair processes in the presence of $A \beta$ was observed for both studied cell lines. There was a decrease in free radical level and DNA damage number compared to control cultures (cells treated with LPS and without $A \beta$ ). The neurotrophic activity of A $\beta$ was observed - the effect on neurites' growth even after the preincubation of PC12 cells with LPS. At the lowest concentration of LPS used, the increase in neurite length was about $50 \%$ greater than in the negative control. At low concentrations, $\mathrm{A} \beta$ has a protective effect on neuron-like PC12 cells pretreated with LPS.
\end{abstract}

Keywords Amyloid- $\beta \cdot$ Lipopolysaccharide $\cdot$ Alzheimer's disease $\cdot$ ROS $\cdot$ DNA damage

\section{Introduction}

Alzheimer's disease (AD) is classified as a neurodegenerative disorder. This disease includes pathological loss of nerve cells and a reduction in the number of synaptic connections along with the loss of their plasticity. The disease develops asymptomatically for many years, and as a consequence, changes in the brain cause difficulties in daily activities, memory loss, mood swings, and changes in behavior. Over time, problems with recalling words or numbers and even disorientation in the family environment appear. The progress of science and technology influenced the development of medicine, the life span of people has significantly increased, and the risk of developing

Benita Wiatrak

benita.wiatrak@umed.wroc.pl

1 Department of Pharmacology, Wroclaw Medical University, Mikulicza-Radeckiego 2, 50-345 Wrocław, Poland

2 Department of Basic Medical Sciences, Wroclaw Medical University, Wrocław, Poland
$\mathrm{AD}$ increases with age. Due to the growing number of patients, the financial outlay for medical care is growing and searching for possible effective therapies. There are still no effective drugs - the currently used drugs can only slow down the disease's progression and do not reverse the changes that have already taken place. It is also a socially burdensome problem, and for family members.

The pathomechanism of $\mathrm{AD}$ is also ambiguous. In the literature, we can read many hypotheses about the development of the disease. The oldest of them is the cholinergic hypothesis. Currently used drugs contain active substances that inhibit the activity of acetylcholinesterase. The next two most popular are the tau protein hyperphosphorylation and the amyloid hypothesis - based on the toxicity of amyloid- $\beta$ (A $\beta)$ plaques. In addition to the toxic properties of $A \beta$, the positive features of this peptide are increasingly being reported. At the clinical/preclinical study stage, the negative effect of compounds with anti-amyloidogenic activity was demonstrated. The phenomenon of $A \beta$ aggregation is a physiological response that shows a strong antimicrobial activity [1-3], by which it protects the brain against the effects of harmful molecules penetrating the blood-brain barrier, by which it 
combines bacterial fragments and forms insoluble pods with them $[2,4]$. Moreover, there is a relationship between the number of bacteria in the types most frequently represented among patients and $\mathrm{AD}$ biomarkers (including the level of $\mathrm{A} \beta_{42} / \mathrm{A} \beta_{40}$ in the cerebrospinal fluid) [5]. A small-group study in Japan showed that reduced numbers of Bacteroides and increased numbers of bacteria labeled "other" are better indicators of $\mathrm{AD}$ than traditional biomarkers such as $\mathrm{ApoE} \varepsilon 4$ or a high result of VSRAD test (voxel-based specific regional analysis system for Alzheimer's disease) [6]. Inflammation, more specifically neuroinflammation, is a factor that can link infections, changes in the microbiota, particles secreted and produced by microorganisms, and changes in the brain leading to the development of AD symptoms [7, 8]. Astrocytes, microglia, and pro-inflammatory cytokines have been observed in the vicinity of amyloid plaques and neurofibrillary tangles for a relatively long time-Alzheimer himself is the first to mention the inflammatory component of the disease image [7-9].

The post-mortem material of patients with $\mathrm{AD}$ revealed bacterial origin particles, including fragments of bacterial cells (peptidoglycan, flagellin, lipopolysaccharide - LPS) and bacterial amyloid [10]. The most important bacterial amyloid curli fimbriae are produced by Escherichia coli (they are biofilm components, biochemically similar to $A \beta$ ). It has been suggested that, due to the similar bacterial structure, amyloids can induce human proteins to adopt the pathological structure of the $\beta$-sheet [11]. LPS is a strong pro-inflammatory agent, and together with amyloid can co-create senile plaques [11-15]. At the same time, it causes cell damage and death in a dose-dependent manner. By interacting with the toll-like 4 receptor (TLR4), LPS activates the NF-KB, p38MAPK, or JNK signaling pathways, resulting in subsequent inflammatory cell damage. Therefore, this particular bacterial cell outer membrane compound is widely used to induce inflammation in neuronal cells in in vitro models of spinal cord injury (SCI) or various neurodegenerative diseases, including $\mathrm{AD}[16,17]$. It has been proved in many experiments that $\mathrm{PC} 12$ cells treated with LPS showed increased production of proinflammatory cytokines such as Il- $1 \beta$, Il- 6 , and TNF- $\alpha$, as confirmed by mRNA expression measurements [18-22]. It is generally recognized that the amount of microglia and amyloid is dependent on each other based on feedback. When the amount of $A \beta$ aggregates increases, they can stimulate tolllike receptors (TLRs) and enhance the inflammatory response $[23,24]$. After TLR2 and TLR4 activation, glial cells and astrocytes release pro-inflammatory cytokines (TNF- $\alpha$, IL$1 \beta$, IL-6, IL-12, IL-18) and anti-inflammatory cytokines (IL10 and TGF- $\beta$ ) $[25,26]$. The presence of $A \beta$ aggregates and damaged and dead cells in the brain tissue permanently stimulates proliferation and activates microglial cells, which maintains the stimulation of non-specific immune response, which affects the release of chronic inflammatory reaction mediators and intensification of the production of reactive oxygen and nitrogen species (ROS and RNS). The persistent stimulation of non-specific immune response is considered a key mechanism is driving the progression of neurodegeneration $[24,27$, 28].

PC12 is a cancer cell line derived from the rat adrenal glands, which, after incubation with nerve growth factor (NGF), differentiates into cells that resemble biochemically and phenotypically sympathetic nerves [29]. The human THP-1 cell line is derived from a human with acute monocytic leukemia. THP-1 cell cultures incubated in the presence of phorbol 12-myristate 13-acetate (PMA) differentiate into microglia-like cells [30]. THP-1 cells treated with PMA are - in terms of morphology, expression of characteristic surface proteins, production of cytokines, and response to various stimuli-similar or even identical to human macrophages. Therefore, THP-1 cells present a suitable macrophage-like model, especially in response to TLR2 agonists (like LPS or amyloid- $\beta$ ) [31]. Expression of the M-phenotype activation markers, namely the pro-inflammatory cytokines Il-1 $\beta$ and TNF- $\alpha$, corresponds to the expression observed in human monocyte-derived macrophage cultures [32-34]. THP-1 induced to differentiation with PMA, after contact with bacterial lipopolysaccharide, also secretes - among other eicosanoid derivatives-PGE2 (prostaglandin E2), which leads to suppression of M2-type polarization and enhanced expression of key markers of M1-phenotype (mainly Il-1 $\beta$ ) [33]. The used concentration of $5 \mathrm{ng} / \mathrm{ml}$ and overall PMA treatment protocol in other studies proved to be sufficient to induce differentiation, ensuring CD14 expression and response to even weak pro-inflammatory stimuli $[31,35]$. At the same time, the relatively low concentration of PMA used in this experiment ensured minimal cell death rate [30]. Both cell lines (PC12 and THP-1) are widely used as models in neurobiological research.

This study aimed to determine whether the presence of low doses of $A \beta$ has a protective effect in cultures of neuron-like and microglia-like cells preincubated with LPS.

\section{Materials and Methods}

\section{Cell Lines and Conditions}

The study was carried out on two cell lines, often used as an in vitro model in neurobiological research. The first cell line was the PC12 line growing in suspension, derived from rat adrenal pheochromocytoma. The second cell line was the THP-1, human monocytic cells obtained from an acute monocytic leukemia patient. Both cell lines were purchased from ATCC. These cell lines were cultured with RPMI-1640. In the case of PC12 cells, the medium was supplemented with $10 \%$ donor horse serum (DHS; EuroClone, Italy), 5\% fetal bovine 
serum (FBS; Biological Industries, USA) with 2 mME Lglutamine and $25 \mu \mathrm{g} / \mathrm{ml}$ gentamicin. In contrast, for THP-1 cells, the same L-glutamine and gentamicin concentrations and only $10 \%$ FBS were applied. These media were used for standard culture. Cell morphology and confluence were assessed using a microscope at least twice a week. The medium with cells was collected into previously prepared and described centrifuge tubes and centrifuged at $1000 \times g$ for $5 \mathrm{~min}$. Then, the supernatant was removed, and fresh medium was added. THP-1 cells were pipetted and counted with a Bürcker chamber. However, the pellet of PC12 cells had to be broken with a syringe with a needle (twice each needle with a diameter of 12, 9, and 6) and then also counted in the Bürcker chamber. For the cell lines used to constitute an appropriate neurobiological model, it was necessary to differentiate them. For this purpose, 1 day after plating the cells, the primary medium was replaced with the differentiation medium. The differentiation medium for PC12 cells contained $100 \mathrm{ng} / \mathrm{ml}$ nerve growth factor (NGF) and for THP-1 cells $50 \mathrm{ng} / \mathrm{ml}$ phorbol 12-myristate 13-acetate (PMA). PC12 cells were differentiated for 3 days, and THP-1 cells for 5 days, with a medium replacement every 2 days. Cultures were incubated at $5 \% \mathrm{CO}_{2}, 95 \%$ humidity, and $37^{\circ} \mathrm{C}$. The tests used differentiation media supplemented similarly with L-glutamine and gentamicin, but the serum was reduced to $1 \%$ DHS for PC12 cells and 1\% FBS for THP-1 cells.

To analyze the neural characteristics of PC12 cells, immunocytofluorescence was performed. For this purpose, the doublecortin (DCX) antibody was used. After incubation with NGF, cells were fixed with $100 \%$ cold methanol for 5 min. The cells were then washed three times with PBST (0.1\% Tween 20 with PBS) for $5 \mathrm{~min}$. Permeabilization was performed with $0.1 \%$ Triton X-100 in PBS for 10 min at RT. The blocking of non-specific antibodies was then carried out with a PBST solution supplemented with $1 \%$ bovine serum albumin (BSA) and 10\% normal goat serum for $30 \mathrm{~min}$. The antibody was prepared by diluting 1:500 in 1\% BSA in PBST. The culture plates were washed three times with PBST for $5 \mathrm{~min}$, and finally, the cells were treated with the antibody solution for $1 \mathrm{~h}$ at room temperature. The plates were washed again and observed under a fluorescence microscope (EVOS FL, Thermo Fisher Scientific).

\section{Tested Compounds}

Lipopolysaccharide (LPS) (cat. no. L2630) from Escherichia coli and amyloid- $\beta$ (25-35) (A $\left.\beta_{25-35}\right)$ (cat. no. A4559) was purchased from Sigma-Aldrich, Saint Louis, USA. Both compounds were dissolved in distilled water to a final stock concentration of $1.0 \mathrm{mM}$. The stock solutions were stored at $20{ }^{\circ} \mathrm{C}$ until use, but not longer than 6 months. For the biological experiments, the LPS was dissolved in the primary medium to a concentration range of $1-100 \mu \mathrm{M}$. The $\mathrm{A} \beta$ was also diluted at the primary medium but to concentrations of $0.001 \mu \mathrm{M}$ and $1.0 \mu \mathrm{M}$.

\section{Modification of the Surface of Culture Plates}

PC12 cells grow in suspension, so to be a neural model, they must be stimulated to adhere to a culture vessel surface. For this purpose, the surface of the culture plates was modified, and the wells were covered with a type I collagen solution (Sigma-Aldrich). The purchased collagen was dissolved in $0.1 \mathrm{M}$ acetic acid to the concentration of $0.1 \%(\mathrm{w} / \mathrm{v})$ and stored at $-20{ }^{\circ} \mathrm{C}$ until the end, but not longer than 6 months. To obtain a working collagen solution, the stock solution was diluted with distilled water to a final concentration of $0.01 \%$ $(\mathrm{w} / \mathrm{v})$. The volume of the working solution necessary to cover the entire surface was pipetted into the well. The plates were left at $4-8{ }^{\circ} \mathrm{C}$ overnight. The following day, the remaining solution was removed, and the covered plates were washed three times for $5 \mathrm{~min}$ with PBS. The prepared plates were stored at $-4{ }^{\circ} \mathrm{C}$ for no longer than a month. Plates were UV irritated for $30 \mathrm{~min}$ before use.

\section{Experiment Design}

After the cells were differentiated, the medium was removed, and the LPS prepared in advance was added for $24 \mathrm{~h}$ at concentrations $(1-100 \mu \mathrm{M})$. The next day the LPS solutions were removed, the culture was washed. The previously prepared $\mathrm{A} \beta$ was added at a concentration of $1.0 \mu \mathrm{M}$ or $0.001 \mu \mathrm{M}$ for the next $24 \mathrm{~h}$ in viability and genotoxicity assays or $1 \mathrm{~h}$ when the ROS level was measured. After this time, tests were performed to assess the viability of cell cultures, the level of free oxygen radicals, and DNA damage.

\section{Viability Assays}

Viability for both cell lines was measured by the MTT assay. Besides, an additional test was performed for PC12 cells by measuring LDH (lactate dehydrogenase) release. These assays were performed at a cell density of 10,000 per well. After incubation of $\mathrm{PC} 12$ cells with $\mathrm{A} \beta$, the supernatant was transferred to new culture plates. To carry out the LDH assay, the reaction mixture was added to the previously collected supernatants and left for $30 \mathrm{~min}$ in the dark. After this time, the stop solution was added, and the absorbance was measured at two lengths, $490 \mathrm{~nm}$ and $680 \mathrm{~nm}$, using a Victor2 multi-plate reader. To perform the MTT assay, the cells of both lines were washed, and $1 \mathrm{mg} / \mathrm{ml}$ MTT (3-(4,5-dimethylthiazol-2-yl)-2,5diphenyltetrazolium bromide) solution in MEM without phenol red was added into the culture. The cells were incubated for $2 \mathrm{~h}$ at $37^{\circ} \mathrm{C}$. The solution was then carefully removed, isopropanol was added, and plates were shaken for $30 \mathrm{~min}$ to 
dissolve the formazan crystals. Finally, the absorbance was measured at $555 \mathrm{~nm}$ using a Victor2.

\section{ROS Level}

The ROS level was measured with DCF-DA assay. Cells were seeded at a density of 20,000 cells/well. After 1-h incubation with $\mathrm{A} \beta$, the solution was removed and added a $20 \mu \mathrm{M}$ DCFDA (2'-7'-dichlorofluorescin diacetate) solution for the next $1 \mathrm{~h}$ at $37^{\circ} \mathrm{C}$. After removal of the supernatant, the cells were washed with PBS, and the fluorescence was measured at with excitation at $485 \mathrm{~nm}$ and emission at $535 \mathrm{~nm}$ using a Victor2.

\section{Fast Halo Assay}

To assess the effect of $A \beta$ on DNA damage in LPS-induced inflammation, the fast halo assay (FHA) was performed. The test was performed at a cell density of 50,000 per well. After incubation with $A \beta$, the supernatant was collected into preprepared tubes, and the culture was washed with PBS and harvested, and the TrypLE solution was added to the plates for $2 \mathrm{~min}$ at $37{ }^{\circ} \mathrm{C}$. After collection of cell suspension, the tubes were centrifuged at $1000 \times g$ for $5 \mathrm{~min}$. The supernatant was removed, and the pellet was resuspended in PBS and again centrifuged under the same conditions. The supernatant was removed again, and the pellet was resuspended to obtain a cell density of 30,000 in $30 \mu \mathrm{L}$ DPBS and the tubes with cells were placed in a water bath at $37^{\circ} \mathrm{C}$. The cell suspension was then mixed with the agarose solution $(1.25 \%$ low melting agarose in PBS), and the cell mixture was immediately pipetted between an agarose coated slide and a coverslip. This preparation was put on a cooling block and left to gel formation. The coverslip was removed, and preparation was put in lysis buffer overnight at $4{ }^{\circ} \mathrm{C}$. The following day, the slides were moved in $\mathrm{pH} 13$ buffer for $30 \mathrm{~min}$ at RT. After this time, the slides were transferred to a neutralization buffer twice for 5 min. Finally, the specimen was stained with $10 \mathrm{mM}$ DAPI solution, and pictures were taken of 50 randomly encountered nuclei in each analyzed slide.

\section{Neuronal Features}

To evaluate neuronal features, the length of the neurites was measured. Only cells whose neurite length was twice the body diameter were assessed. Additionally, the number of neurites for each cell was counted. Calculations were performed for 100 randomly selected cells (from numerous micrographs taken) in 5 independent experiments. The ImageJ image analysis software was used to count and measure neurites on microscopic images. Those neurites for which it was certain which the cell neurite originated and where it ends were assessed.

\section{Statistical Analysis}

The results are presented as mean \pm SEM. In this study, two control groups were used: negative control was cultured only primary medium without LPS, and $A \beta$ and positive control were grown only with LPS without $A \beta$. The distribution of the results was normal, and the equality of variance was confirmed with Levene's test, so statistical significance was calculated using parametric tests-ANOVA and the appropriate post hoc test. The $p<0.05$ was considered the significance point. The Statistica v13.1 software was used for statistical analysis.

\section{Results}

Immunocytofluorescence staining was performed to check whether the cultures show neuron-like features after 72-h incubation of PC12 cells with NGF. For this purpose, PEconjugated doublecortin (DCX) was used. The doublecortin protein is characteristic of young developing neurons $[29,36$, 37]. After staining, it was shown that PC12 cells after $72 \mathrm{~h}$ of incubation with NGF-containing medium express doublecortin protein (Fig. 1a). Figure 1b shows the culture of THP-1 cells after incubation with PMA for 5 days. As a result of the incubation of the monocyte line in the medium containing PMA, the cell morphology changed - from cell suspension to cells adhering to culture vessels' surface. Simultaneously, a change in the cells' shape was observed - from spherical, almost identical cells, the culture became heterogeneous - flattened and round cells and cells with a significantly increased body size were observed along with the reorganization of the cytoskeleton and the development of branches, which constituted about $80 \%$ of cells in the field of view [38].

To investigate the effect of $A \beta$ on the viability of two cell lines: PC12 after differentiation from nerve growth factor (NGF) and THP-1 after PMA treatment after prior LPS exposure, metabolic activity (MTT assay) was assessed (Fig. 2a and b). A statistically significant decrease in metabolic activity after incubation with LPS was observed in both PC12 and THP-1 cells (except $1 \mu \mathrm{M}$ in PC12 cells). A concentration dependence was observed in the PC12 cell line. However, in the THP-1 line, regardless of the concentration used, a decrease in viability by about $20 \%$ was observed. Both $0.001 \mu \mathrm{M}$ and $1.0 \mu \mathrm{M}$ concentrations of $\mathrm{A} \beta$ influence the reduction of negative impact LPS on both cell lines.

The level of lactate dehydrogenase (LDH) release was also assessed, which indirectly indicates the number of necrotic cells in culture after incubation with LPS and then with $A \beta$. After PC12 cells were incubated in the presence of LPS, a concentration-dependent increase in the amount of released lactate dehydrogenase was observed. A statistically significant reduction in lactate dehydrogenase leakage was observed after 
Fig. 1 PC12 cells after immunocytofluorescence staining with doublecortin (DCX) antibody conjugated with PE fluorochrome (a); morphology of the THP-1 cells after PMA treatment (b)
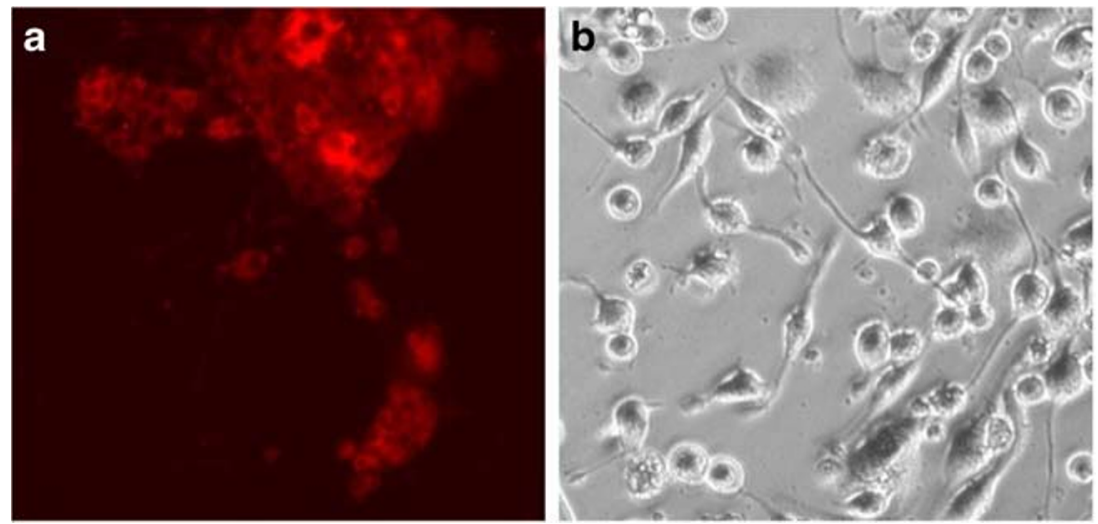

incubation with $\mathrm{A} \beta$. The regenerative effect of the $1.0 \mu \mathrm{M} \mathrm{A} \beta$ was significantly strong (reduction of LDH leakage was observed) even compared to the negative control (PC12 culture only on LPS and $A \beta$ free medium) after preincubating the culture in the range $1-50 \mu \mathrm{M}$ LPS. In contrast, a similar LDH leakage reduction effect (about 20\%) compared to the negative control was seen with $0.001 \mathrm{~A} \beta$ only at $1.0 \mu \mathrm{M}$ LPS.

To assess intracellular ROS, accumulation was measured with the DCF-DA assay (Fig. 3a and b). This study demonstrated a higher level of reactive oxygen species in PC12 cells than in THP-1 cells after LPS treatment. In both cell lines, an increase in ROS dependent on LPS concentration was observed. After applying the concentration of 0.001 and $1.0 \mu \mathrm{M} \mathrm{A} \beta$, the peptide's regenerative effect was observed. That is, it reduced the level of free oxygen radicals (statistically significant). In both lines (PC12 and THP-1) after incubation with A $\beta$, regardless of the concentration used, a reduction in free oxygen radicals was observed to the level seen in the negative control after prior
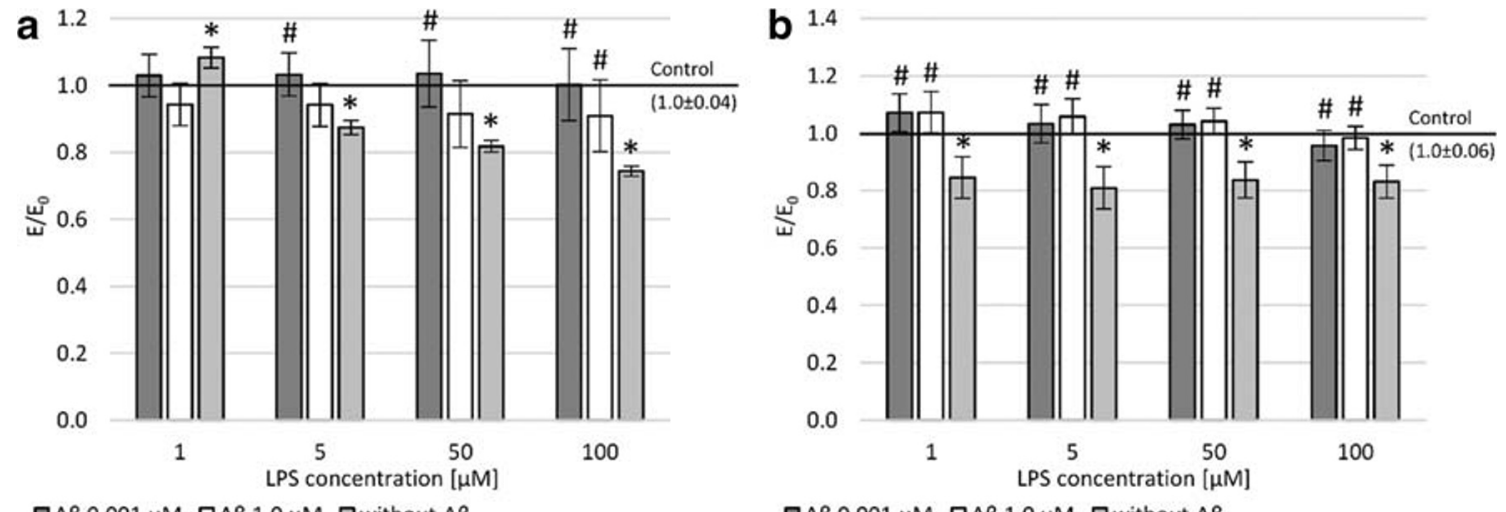

$\square A B 0.001 \mu \mathrm{M} \square \mathrm{AB} 1.0 \mu \mathrm{M}$ Qwithout $A \beta$

$\square A \beta 0.001 \mu M \quad \square A B 1.0 \mu M \quad \square$ without $A \beta$

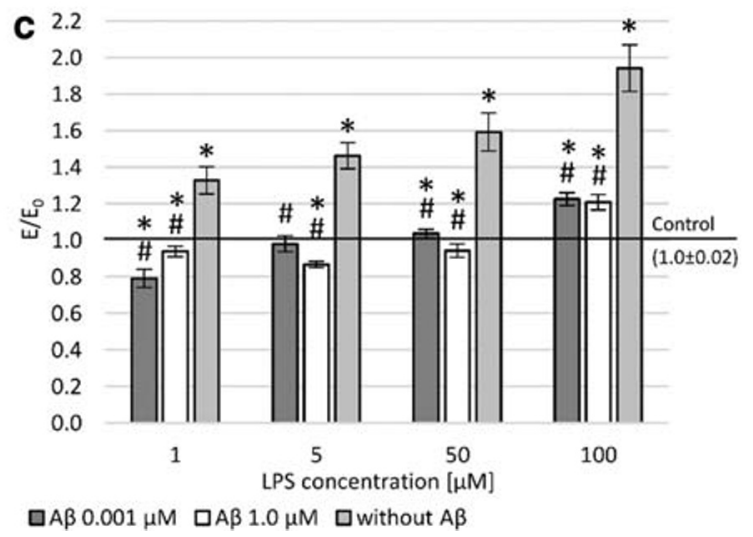

Fig. 2 Effect of $\mathrm{A} \beta$ on PC12 cells (a and c) and THP-1 (b) cells preincubated with lipopolysaccharide (LPS); metabolic activity measured in MTT assay (a and b), cell viability measured in LDH assay (c); control- cell culture incubated without LPS and A $\beta ; * p<0.05$ - significant difference compared to a negative control without LPS; \# $p<0.05$ - significant difference compared to control preincubated with LPS 


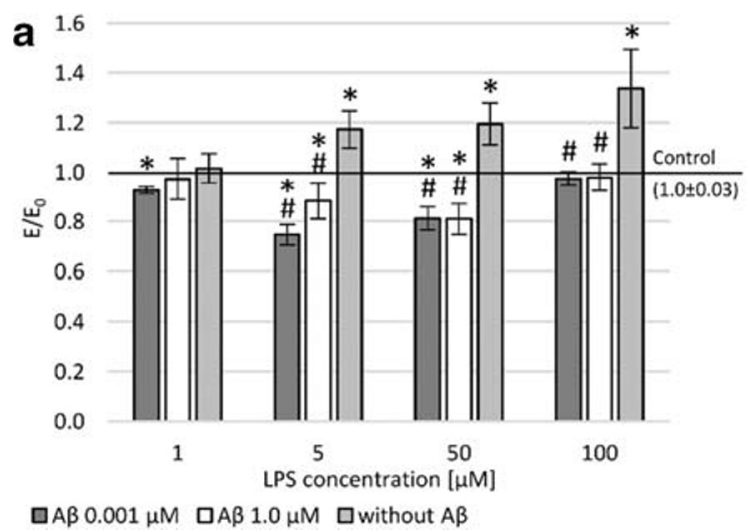

Fig. 3 Effect of A $\beta$ on PC12 cells (a) and THP-1 (b) cells preincubated with lipopolysaccharide (LPS); (a and b) DCF-DA assay; control—cell culture incubated without LPS and $\mathrm{A} \beta ; * p<0.05$ - significant difference

incubation with $100 \mu \mathrm{M}$ LPS. A similar effect was demonstrated in the THP-1 line after incubation with a concentration of $50 \mu \mathrm{M}$ LPS and PC12 cell line after treatment with a concentration of $1 \mu \mathrm{M}$ LPS. In other cases, a statistically significant reduction in the level of free oxygen radicals was observed compared to the negative control.

It is well known that high levels of ROS can lead to doublestrand break (DSB). Accordingly, a fast halo assay (FHA) was performed, which measured the nuclear size of the halo (chromatin dispersion). In LPS-induced cells, the number of DSBs was almost twice and four times higher compared to the negative control at the highest concentration tested $(100 \mu \mathrm{M})$ in the culture of THP-1 and PC12 cells, respectively (Fig. 4a and b). $A \beta$ in concentrations of 0.001 and 1.0 showed a regenerative effect on damage to DNA strand breaks after prior incubation with LPS.

To evaluate the impact on the neuronal feature of PC12 cells, the average length of neurites (Fig. 5a) and the average number of neurites (Fig. 5b) were analyzed. Incubation with LPS caused a statistically significant decrease in neurite length (to up $60 \%$ in higher concentration). For all concentrations of

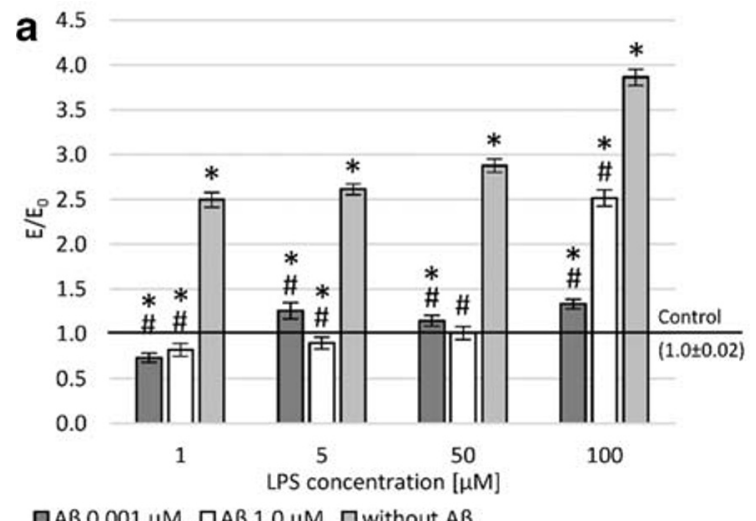

Fig. 4 Effect of $\mathrm{A} \beta$ on PC12 cells (a) and THP-1 (b) cells preincubated with lipopolysaccharide (LPS); (a and b) fast halo assay; control-cell culture incubated without LPS and $\mathrm{A} \beta ; * p<0.05$ - significant difference

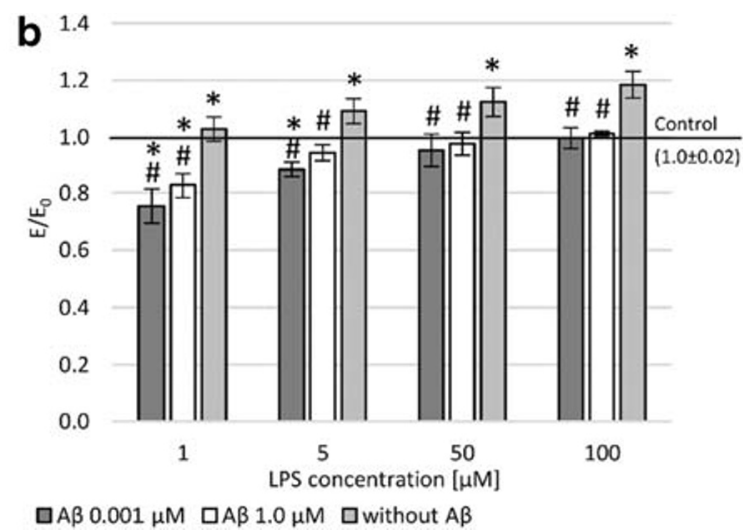

compared to a negative control without LPS; \# $p<0.05$ - significant difference compared to control preincubated with LPS

$\mathrm{A} \beta$, an increase in the average length of measured neurites was shown compared to LPS-induced cells. The neurite growth was statistically significantly greater after applying $A \beta$ at a concentration of $0.001 \mu \mathrm{M}$ than at $1.0 \mu \mathrm{M}$. At the same time, this increase was comparable to the negative control.

The average number of neurites after incubation of cells with LPS was statistically significantly lower in the concentration range of 5-100 $\mu \mathrm{M}$ compared to the negative control. Moreover, the reduction in the number of neurites was concentration-dependent. An increase in the mean number of neurites was demonstrated after incubating the culture with $\mathrm{A} \beta$ at both 0.001 and $1.0 \mu \mathrm{M}$ concentrations. The average neurite length was $40 \mu \mathrm{m}$ for negative control. It is worth noting that after incubation with $A \beta$ at a concentration of $0.001 \mu \mathrm{M}$, a neurotrophic activity could be observed, and the average length of neurites was about $58 \mu \mathrm{m}$ (Fig. 5a). Figure 6 shows exemplary micrographs showing the morphology of PC12 cells. The longest neurites are in Fig. $6 \mathrm{e}(1.0 \mu \mathrm{M}$ LPS and $0.001 \mu \mathrm{MA} \beta$ ), and the culture shown in Fig. $6 \mathrm{~d}$ $(100.0 \mu \mathrm{M}$ LPS without $\mathrm{A} \beta$ ) is characterized by the shortest neurites.

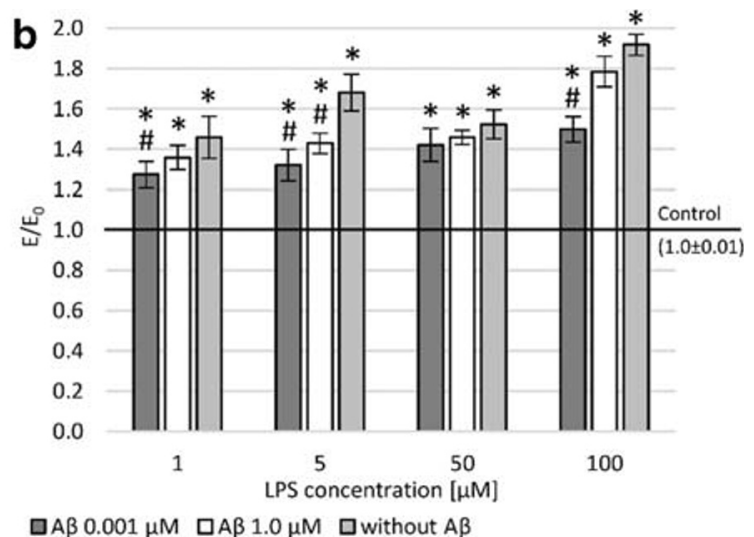

compared to a negative control without LPS; \# $p<0.05$ - significant difference compared to control preincubated with LPS 


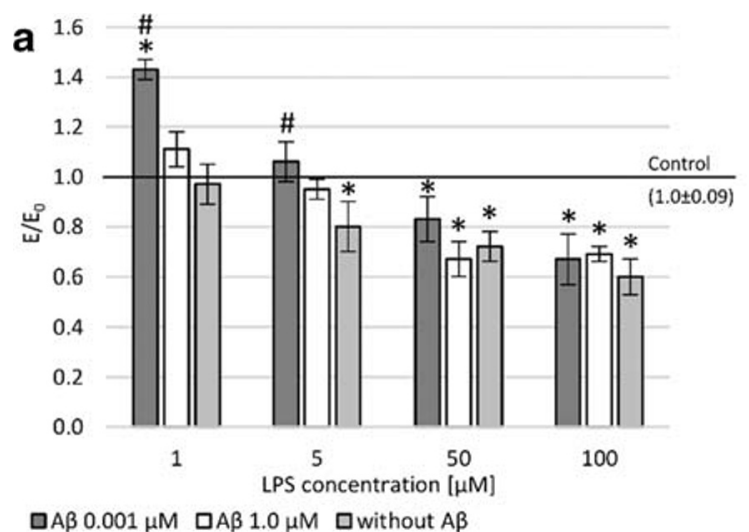

Fig. 5 Effect of $\mathrm{A} \beta$ on $\mathrm{PC} 12$ cells preincubated with lipopolysaccharide (LPS); average length of neurites (a), an average number of neurites (b); control-cell culture incubated without LPS and A $\beta ; * p<0.05-$

\section{Discussion}

A growing body of evidence suggests that amyloid- $\beta$ - considered for a long time to be a hallmark for pathology with no physiological function - may have antimicrobial properties as a part of the innate immune system. A $\beta$ molecules share some striking similarities with recently recognized antimicrobial peptides (AMPs) - potent antibiotics with immunomodulatory properties produced in human bodies - together with its most thoroughly studied representative LL-37 protein. The tendency to self-assemble to form oligomers in pathology may lead to creating senile plaques typical for Alzheimer's disease. Still, it has been proven that $A \beta$ oligomerization
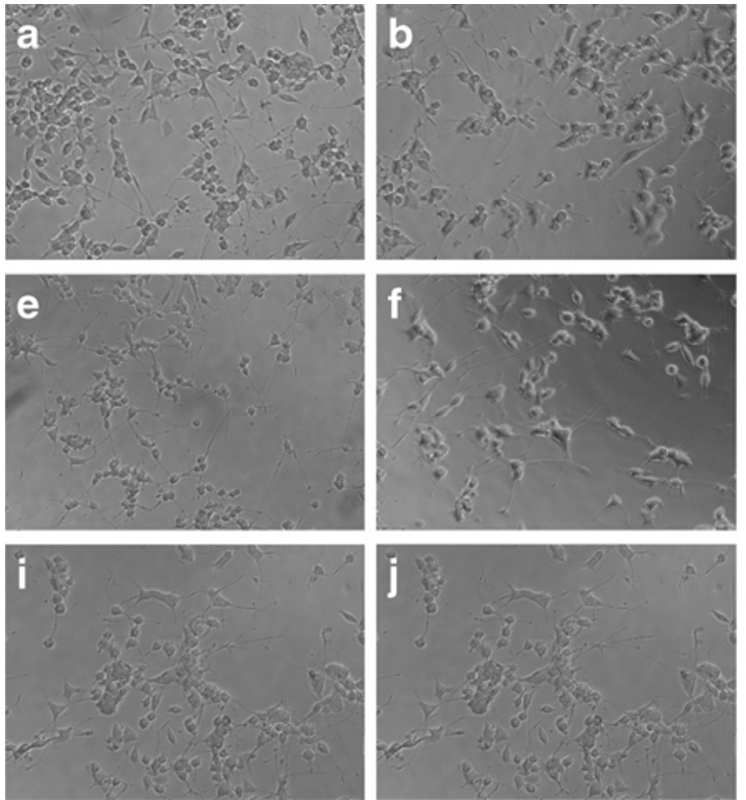

Fig. 6 Effect of $\mathrm{A} \beta$ on $\mathrm{PC} 12$ cells preincubated with lipopolysaccharide (LPS); incubation without $A \beta$ (a-d), with $A \beta$ at a concentration of $0.001 \mu \mathrm{M}(\mathbf{e}-\mathbf{h})$, and with $\mathrm{A} \beta$ at a concentration of $1 \mu \mathrm{M}(\mathbf{i}-\mathbf{l}) ;$ LPS at a

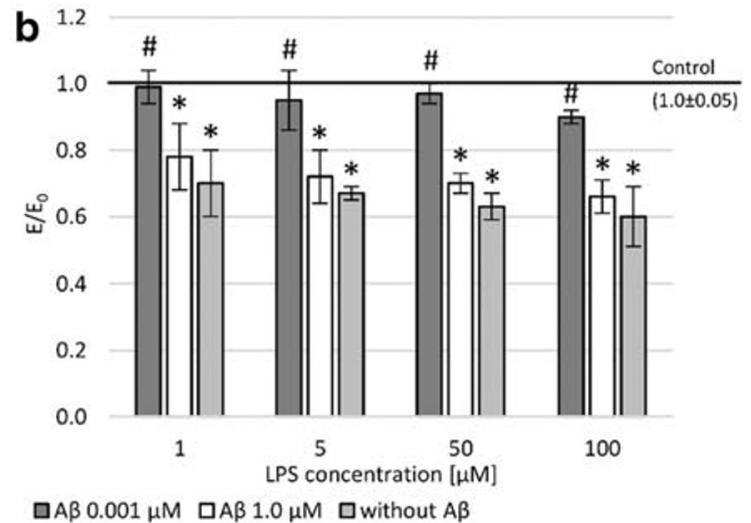

significant difference compared to a negative control without LPS; \# $p<0.05$ - significant difference compared to control preincubated with LPS

enables binding, agglutination, and entrapment of certain pathogens while inhibiting their adhesion preventing the spread of infection and facilitating phagocytosis [1, 2, 39-41]. A $\beta$ molecular structure, just like LL-37, contains a heparin-binding motif enabling attachment to carbohydrates being a part of the microbial cell wall $[2,42]$. As studies show, $\mathrm{A} \beta$ can stop microbes from spreading and may kill viruses, fungi, and bacteria. Microbicidal properties of known AMPs usually stem from their capability to self-aggregate in the form of fibrils and interacting with negatively charged microbial plasma membranes (and sometimes mitochondria in line with the endosymbiotic theory of their origin), leading to uncontrolled ion leakage and death of attacked cell [4, 42, 43].
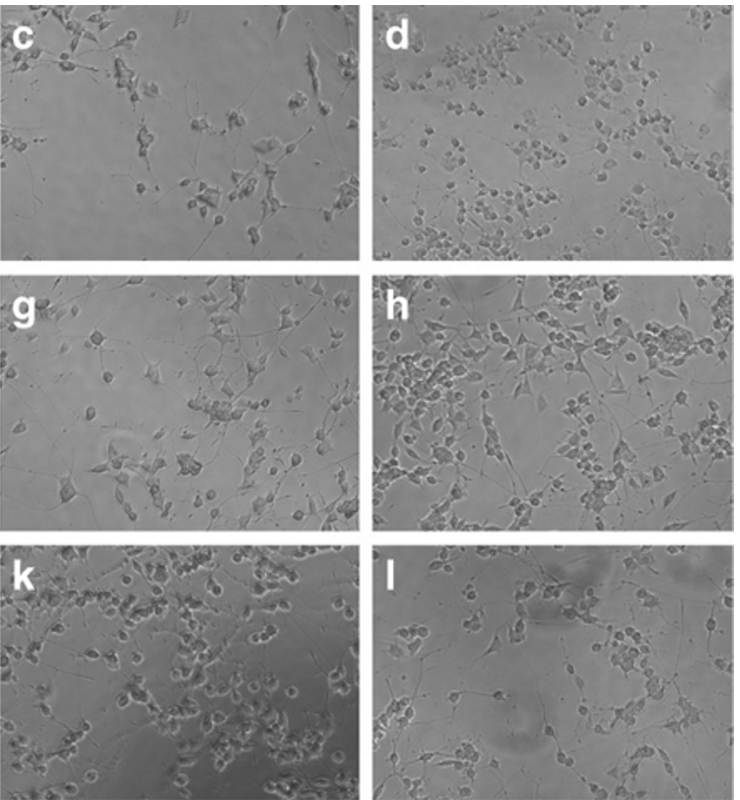

concentration of $1.0 \mu \mathrm{M}(\mathbf{a}, \mathbf{e}, \mathbf{i}), 5.0 \mu \mathrm{M}(\mathbf{b}, \mathbf{f}, \mathbf{j}), 50.0 \mu \mathrm{M}(\mathbf{c}, \mathbf{g}, \mathbf{k})$, and $100.0 \mu \mathrm{M}(\mathbf{d}, \mathbf{h}, \mathbf{l})$; objective magnification: $\times 10$ 
Numerous studies report that circulating concentrations of amyloid- $\beta$ (including neurotoxic oligomers) vary immensely between $\mathrm{AD}$ patients [44], probably due to various measuring methods and inconsistency in the preanalytical treatment of specimens. It is already established that plasma levels of amyloid- $\beta$ correlate poorly with patients' clinical conditions [45]. Therefore in our study, we chose concentrations of soluble amyloid- $\beta$ observed in brain homogenates and CSF (cerebrospinal fluid) of $\mathrm{AD}$ subjects that are ranging from nanomoles $[46,47]$ to micromoles [47-50]. Concentrations of $1 \mathrm{nM}$ and $1 \mu \mathrm{M}$, respectively, were selected due to the neurotrophic properties of nanomolar concentrations of $A \beta_{25-35}$ [51] and reported (dose-dependent) neurotoxicity of micromolar concentrations [52, 53].

As early as the 1990 s, scientists tried to draw attention to the positive effects of $A \beta$ in cell cultures. Luo et al. proved that in the culture of $\mathrm{PC} 12$ cells, $A \beta$ at a concentration of $1 \mathrm{nM}$ had a pro-proliferative effect (even stronger than BSA administration). Moreover, $A \beta_{25-35}$ has been shown to have a stronger pro-proliferative activity compared to the two more frequently studied $A \beta$ fragments, $1-40$ and 1-42 [54]. The next step in demonstrating the positive effect of $A \beta$ on cell cultures was to evaluate its effect on PC12 cells during differentiation. Yanker et al. observed that during the first $48 \mathrm{~h}$ of differentiation, the presence of $A \beta_{1-40}$ showed a neurotrophic activity, while in the following days, it was neurotoxic. At the same time, $A \beta_{25-35}$ was shown to have a stronger neurotrophic effect compared to other fragments, and the impact on the viability was not so pronounced [51]. The neurotrophic effect of $\mathrm{A} \beta_{1-42}$ (even at a concentration of $1.0 \mu \mathrm{M}$ ) was also demonstrated in the cultures of neural stem cells [55]. An interesting observation was also made by Arevalo et al., who conducted in vitro studies on neurons isolated from the mouse hippocampus. They added to the cell culture $\mathrm{A} \beta$ at a concentration of $20 \mathrm{nM}$ and $800 \mathrm{nM}$. They found that the low concentration had a positive effect on the length of neurites but reduced the density. The opposite effect was observed at a higher concentration (800 nM) [56]. In our study, it was shown that amyloid in low concentrations has a regenerative effect on neuron-like cells (PC12) and influenced the viability and growth as well as the number of neurites in the culture after prior incubation of the culture with LPS. It has also been shown that physiologically low concentrations of $A \beta$ have neurotrophic properties. We noticed that a low concentration of $\mathrm{A} \beta(0.001 \mu \mathrm{M})$ had a strong neurotrophic effect on neurite length, while the effect on neurite density was comparable to the control (without LPS).

Reactive oxygen species production catalyzed by bound metal (zinc or copper) and activating complement are also mediated by oligomers formation [39]. As a member of the AMP group, $A \beta$ is an agent of the innate immune response in the immune-privileged brain, and its expression is heightened not only in $\mathrm{AD}$ but also in neuroborreliosis, neurosyphilis,
HIV-related dementia, herpes simplex encephalitis, and Chlamydia brain infection [1, 40, 41, 57]. Further proving $\mathrm{A} \beta$ peptide's engagement in immune response in the brain, apolipoprotein $\mathrm{E}$ is suggested to be a part of innate immunity and its homozygous variant $\varepsilon 4$ - the major genetic risk factor for sporadic Alzheimer's disease - is associated with increased susceptibility to some pathogenic microbes including neurotropic viruses [39, 41]. Additionally, the brains of patients with $\mathrm{AD}$ tend to show higher viral or bacterial loads than their age-matched controls. A large proportion of $A \beta$-formed plaques contains particles and genetic material of viruses and bacteria [41]. We proved that fragments of bacterial cells, in this case, LPS, caused an increase in the level of free oxygen radicals after 24-h incubation of PC12 cultures with LPS. In contrast, the incubation of $\mathrm{PC} 12$ cell cultures with $\mathrm{A} \beta$ caused the scavenging of free radicals. At the same time, along with a decrease in the level of free oxygen radicals, the regeneration of DNA strand damage was observed.

Antimicrobial properties of $A \beta$, either synthetically produced or obtained from the brain and temporal lobe homogenates of $\mathrm{AD}$ patients and $\mathrm{A} \beta$-overexpressing transgenic animals, have been proven in vitro for a variety of pathogenic microbes, including Gram-positive and Gram-negative bacteria, viruses like influenza $A$ and herpes simplex virus type 1, and also Candida albicans $[1,4,39,41] . \mathrm{A} \beta_{1-42}$ showed higher than $A \beta_{1-40}$ antimicrobial activity and the ability to agglutinate pathogens, which might be connected to hydrophobicity and readiness to self-aggregate $A \beta_{1-42}$. Observed effects were obliterated after treatment with anti-amyloid beta antibodies [1, 2, 40, 43]. In vivo experiments revealed a higher survival rate of $A \beta$-overexpressing $5 \mathrm{xFAD}$ mice infected intracerebrally with Salmonella Typhimurium with lower cerebral bacterial loads than their non-transgenic littermates [2,39, 41]. Similarly, transgenic nematodes Caenorhabditis elegans producing $\mathrm{A} \beta_{1-42}$ isoform (GMC101) showed reduced mortality after $C$. albicans infection than control CL2122 worms $[2,39,41]$.

Treatments targeted at amyloid- $\beta$ oligomers and fibrils perceived then as purely pathological structures showed numerous side effects in clinical trials, including a higher risk of meningitis and upper respiratory tract infections. They increased blood-brain barrier permeability leading to edema, micro-hemorrhages, and neurovascular disturbances $[1,39$, $41,42]$. Adverse effects of anti- $A \beta$ therapy seem to be directly or indirectly related to disturbed physiological functions of said peptide.

$\mathrm{A} \beta$ senile plaques, which may also contain other proteins and fragments of bacterial cells, including LPS, cannot be effectively removed by microglial cells. These deposits strongly activate pro-inflammatory signaling pathways in brain tissue cells (including cytokines) and increase the production of reactive oxygen and nitrogen species [25]. The role of the activation of the non-specific immune response 
pathway in the development of neurodegeneration may be an attractive target for future therapy because post-mortem studies of brain tissue in people with mild cognitive impairment (MCI) showed a significant increase in the number of activated microglial cells (immunophenotype M2) and a significant increase in the activity of the NLRP3-caspase complex 1 [23]. An important mechanism driving the progress of neurodegenerative processes is the persistent inflammation caused by the activation of a non-specific immune response leading to the release of pro-inflammatory cytokines and the maintenance of neuronal oxidative stress. The presence of $A \beta$ oligomers inside cells, extracellular deposits of $A \beta$ aggregates in senile plaques, and the presence of damaged and dead cells in brain tissue can induce a non-specific immune response in Alzheimer's disease. The neuroprotective task of astrocytes and microglia is the removal of apoptotic and necrotic cells and amyloid aggregates from the brain tissue [58, 59]. However, excessive proliferation of glial cells and their activation can exacerbate the inflammatory process, damage neurons, and affect the loss of synaptic spines, thereby reducing synaptic function [58-60]. At the same time, the multiplication and activation of microglia cells are associated with the constant presence of $A \beta$ aggregates and damaged and dead cells in the brain tissue, which affects the increased production of ROS and reactive forms of nitrogen (RNS) and the release of chronic inflammatory mediators. Long-term stimulation of non-specific immune response is believed to be a key mechanism driving neurodegeneration progression [24, 27, 28]. In connection with the "vicious circle" between $A \beta$ level and microglia amount, we wanted to see how bacterial particle (LPS) fragments affect microglia cells and then whether the physiological $A \beta$ concentration would have a regenerative effect on LPS damage. The study showed that LPS increased the level of free oxygen radicals and damaged DNA strands in microglia cells. At the same time, incubation with $A \beta$ at physiological concentrations caused less damage to both the DNA strand and the ROS level than after incubation with LPS. The incubation of microglia with LPS caused a decrease in cells' metabolic activity, while incubation with $A \beta$ resulted in activity similar to the negative control. This may indicate a persistent balance between the $A \beta$ and the microglia. The presence of amyloid reduced the level of ROS, similar to the negative control. Only the regeneration of DNA damage was weaker. The likely mechanism of action of $A \beta$ on nerve cells and microglia is shown in Fig. 7.

The condition of the patient's microbiota may be of great importance in Alzheimer's disease. The variety of microorganisms plays a significant role in digestion and providing the host with nutrients. However, if these organisms, their fragments, or substances produced by them cross the intestinal epithelium's protective barrier, it can pose a serious threat. Microorganisms do not even have to leave the gastrointestinal tract to influence metabolism, immune response, and even host behavior, which may be related to the "microbiota-gut-brain axis". The intestinal microbiota contacts the central nervous system through a complex network of signals consisting of neurotransmitters, conduction of stimuli through the vagus nerve and the autonomic nervous system, and secreted short-chain fatty acids (SCFAs), micro RNA (miRNA), small non-coding (sncRNA), and other active molecules, as well as changes in the permeability of the blood-brain barrier (BBB) [14, 61-63]. Our study demonstrated the toxic effect of bacterial LPS on neuron-like and microglia-like cells, as well as the regenerative effect of low doses of $A \beta$. This is another step that challenges the amyloid hypothesis. It seems likely that high $A \beta$ levels are only the brain's response to an excess of harmful factors (including LPS) that lead to neuroinflammation.

This work's limitation is the lack of analysis of the influence of co-cultures of neuronal cells and microglia. The authors plan to conduct such research in the next stage of work.

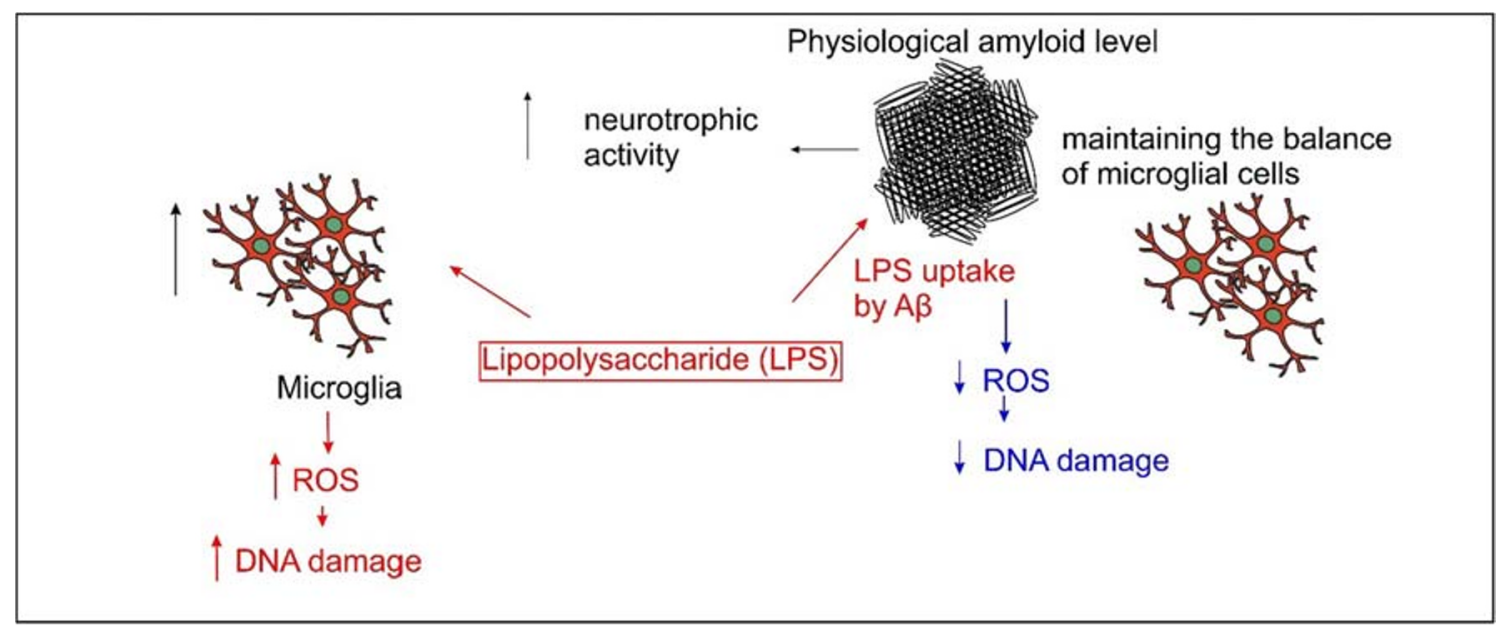

Fig. 7 Likely mechanism of action of $\mathrm{A} \beta$ at physiological concentrations 
It is also planned to determine the level of pro-inflammatory cytokines in cultures. Moreover, the concept of this study was based on the hypothesis of amyloid cascade and neuroinflammation as the main pathomechanism involved in Alzheimer's disease and especially on the idea that amyloid- $\beta$, as a member of AMPs (antimicrobial proteins), could have a beneficial effect on neuronal cells in the presence of bacterial LPS and that disturbance in the physiological pathways involving $A \beta$ and causing neuroinflammation might be the underlying cause of Alzheimer's disease development [64-66]. However, emerging new studies suggest that a model based on tau protein pathology should also be considered in terms of the development and propagation of the disease. Tau burden correlates with clinical symptoms and is needed in some in vitro studies or animal models of AD for the appearance of neuronal damage $[64,65,67,68]$. Therefore, the inclusion of tau protein in future research, in addition to amyloid- $\beta$, could result in a new and better understanding of the mechanisms leading to $\mathrm{AD}$ pathology, especially as there are still few experiments considering tau hyperphosphorylation as more than just an $A \beta$-induced phenomenon [68-71].

In conclusion, LPS in the entire range of concentrations tested increased ROS levels and frequency of DNA damage in THP-1 and PC12 cultures and did not affect neurite growth in $\mathrm{PC} 12$ cells. In contrast, $A \beta$ at low concentrations $[0,001-$ $0.1 \mu \mathrm{M}]$ did not increase toxicity, DNA damage, and ROS levels in THP-1 and PC12 cultures, while significantly increased neurite growth in PC12 cultures. Further research is needed to confirm the neuroprotective effect of these low (close to physiological) $A \beta$ concentrations.

Author Contributions Benita Wiatrak and Katarzyna Balon performed the in vitro experiments, collected data, and wrote the manuscript; Benita Wiatrak designed the study, prepared the figures, and analyzed the results. Both authors read and approved the final version of the manuscript.

Funding The study was supported by funding from Wroclaw Medical University.

Data Availability The datasets generated and analyzed during the current study are available from the corresponding author upon reasonable request.

\section{Compliance with Ethical Standards}

This in vitro study did not include experiments on animals or human participants. The study used only commercially available cell lines from ATCC collection and no ethical approval is required.

Conflict of Interest The authors declare that they have no conflict of interest.

Consent to Participate Not applicable.

Consent for Publication Not applicable.
Open Access This article is licensed under a Creative Commons Attribution 4.0 International License, which permits use, sharing, adaptation, distribution and reproduction in any medium or format, as long as you give appropriate credit to the original author(s) and the source, provide a link to the Creative Commons licence, and indicate if changes were made. The images or other third party material in this article are included in the article's Creative Commons licence, unless indicated otherwise in a credit line to the material. If material is not included in the article's Creative Commons licence and your intended use is not permitted by statutory regulation or exceeds the permitted use, you will need to obtain permission directly from the copyright holder. To view a copy of this licence, visit http://creativecommons.org/licenses/by/4.0/.

\section{References}

1. Soscia SJ, Kirby JE, Washicosky KJ, Tucker SM, Ingelsson M, Hyman B, Burton MA, Goldstein LE et al (2010) The Alzheimer's disease-associated amyloid $\beta$-protein is an antimicrobial peptide. PLoS One 5:e9505. https://doi.org/10.1371/journal. pone.0009505

2. Kumar DKV, Choi SH, Washicosky KJ et al (2016) Amyloid- $\beta$ peptide protects against microbial infection in mouse and worm models of Alzheimer's disease. Sci Transl Med 8:340ra72. https:// doi.org/10.1126/scitranslmed.aaf1059

3. Schwartz K, Boles BR (2013) Microbial amyloids-functions and interactions within the host. Curr Opin Microbiol 16:93-99. https://doi.org/10.1016/j.mib.2012.12.001

4. Brothers HM, Gosztyla ML, Robinson SR (2018) The physiological roles of amyloid- $\beta$ peptide hint at new ways to treat Alzheimer's disease. Front Aging Neurosci 10:118. https://doi.org/10.3389/ fnagi.2018.00118

5. Vogt NM, Kerby RL, Dill-McFarland KA et al (2017) Gut microbiome alterations in Alzheimer's disease. Sci Rep 7:13537. https://doi.org/10.1038/s41598-017-13601-y

6. Saji N, Niida S, Murotani K, Hisada T, Tsuduki T, Sugimoto T, Kimura A, Toba K et al (2019) Analysis of the relationship between the gut microbiome and dementia: a cross-sectional study conducted in Japan. Sci Rep 9:1008. https://doi.org/10.1038/s41598-01838218-7

7. Alkasir R, Li J, Li X, Jin M, Zhu B (2017) Human gut microbiota: the links with dementia development. Protein Cell 8:90-102. https://doi.org/10.1007/s13238-016-0338-6

8. Minter MR, Taylor JM, Crack PJ (2016) The contribution of neuroinflammation to amyloid toxicity in Alzheimer's disease. J Neurochem 136:457-474. https://doi.org/10.1111/jnc.13411

9. Pimplikar SW (2014) Neuroinflammation in Alzheimer's disease: from pathogenesis to a therapeutic target. J Clin Immunol 34:64 69. https://doi.org/10.1007/s10875-014-0032-5

10. Sobol CV (2018) Role of microbiota in neurodegenerative diseases. Russ J Dev Biol 49:297-313. https://doi.org/10.1134/ S1062360418060061

11. Kowalski K, Mulak A (2019) Brain-gut-microbiota axis in Alzheimer's disease. J Neurogastroenterol Motil 25:48-60. https://doi.org/10.5056/jnm18087

12. Sochocka M, Donskow-Łysoniewska K, Diniz BS, Kurpas D, Brzozowska E, Leszek J (2019) The gut microbiome alterations and inflammation-driven pathogenesis of Alzheimer's disease - a critical review. Mol Neurobiol 56:1841-1851. https://doi.org/10. 1007/s12035-018-1188-4

13. Zhan X, Stamova B, Sharp FR (2018) Lipopolysaccharide associates with amyloid plaques, neurons and oligodendrocytes in 
Alzheimer's disease brain: a review. Front Aging Neurosci 10:42. https://doi.org/10.3389/fnagi.2018.00042

14. Zhao Y, Cong L, Lukiw WJ (2017) Lipopolysaccharide (LPS) accumulates in neocortical neurons of Alzheimer's disease (AD) brain and impairs transcription in human neuronal-glial primary co-cultures. Front Aging Neurosci 9:407. https://doi.org/10.3389/fnagi. 2017.00407

15. Zhan X, Stamova B, Jin L-W, DeCarli C, Phinney B, Sharp FR (2016) Gram-negative bacterial molecules associate with Alzheimer disease pathology. Neurology 87:2324-2332. https:// doi.org/10.1212/WNL.0000000000003391

16. Park BS, Lee J-O (2013) Recognition of lipopolysaccharide pattern by TLR4 complexes. Exp Mol Med 45:e66. https://doi.org/10. 1038/emm.2013.97

17. Batista CRA, Gomes GF, Candelario-Jalil E, Fiebich BL, de Oliveira ACP (2019) Lipopolysaccharide-induced neuroinflammation as a bridge to understand neurodegeneration. Int J Mol Sci 20: 2293. https://doi.org/10.3390/ijms20092293

18. Zhang G, Liu Y, Xu L, Sha C, Zhang H, Xu W (2019) Resveratrol alleviates lipopolysaccharide-induced inflammation in PC-12 cells and in rat model. BMC Biotechnol 19:10. https://doi.org/10.1186/ s12896-019-0502-1

19. Li R, Yin F, Guo Y, Ruan Q, Zhu Q (2018) Angelica polysaccharide protects PC-12 cells from lipopolysaccharide-induced injury via down-regulating microRNA-223. Biomed Pharmacother 108: 1320-1327. https://doi.org/10.1016/j.biopha.2018.09.147

20. Sun Y, Liu B, Zheng X, Wang D (2019) Notoginsenoside R1 alleviates lipopolysaccharide-triggered PC-12 inflammatory damage via elevating microRNA-132. Artif Cells Nanomed Biotechnol 47:1808-1814. https://doi.org/10.1080/21691401.2019.1610414

21. Ma S, Zhang C, Zhang Z, Dai Y, Gu R, Jiang R (2019) Geniposide protects PC12 cells from lipopolysaccharide-evoked inflammatory injury via up-regulation of miR-145-5p. Artif Cells Nanomed Biotechnol 47:2875-2881. https://doi.org/10.1080/21691401. 2019.1626406

22. Jiang J, Wang G (2020) Matrine protects PC12 cells from lipopolysaccharide-evoked inflammatory injury via upregulation of miR-9. Pharm Biol 58:314-320. https://doi.org/10.1080/ 13880209.2020.1719165

23. Heneka MT, Kummer MP, Stutz A, Delekate A, Schwartz S, Vieira-Saecker A, Griep A, Axt D et al (2013) NLRP3 is activated in Alzheimer's disease and contributes to pathology in APP/PS1 mice. Nature 493:674-678. https://doi.org/10.1038/nature11729

24. Gasiorowski K, Brokos B, Echeverria V, Barreto GE, Leszek J (2018) RAGE-TLR crosstalk sustains chronic inflammation in neurodegeneration. Mol Neurobiol 55:1463-1476. https://doi.org/10. 1007/s12035-017-0419-4

25. Piirainen S, Youssef A, Song C, Kalueff AV, Landreth GE, Malm T, Tian L (2017) Psychosocial stress on neuroinflammation and cognitive dysfunctions in Alzheimer's diseasethe emerging role for microglia? Neurosci Biobehav Rev 77:148-164. https://doi. org/10.1016/j.neubiorev.2017.01.046

26. Wang W-Y, Tan M-S, Yu J-T, Tan L (2015) Role of proinflammatory cytokines released from microglia in Alzheimer's disease. Ann Transl Med 3:136. https://doi.org/10.3978/j.issn. 2305-5839.2015.03.49

27. Leszek J, Barreto GE, Gąsiorowski K et al (2016) Inflammatory mechanisms and oxidative stress as key factors responsible for progression of neurodegeneration: role of brain innate immune system. CNS Neurol Disord Drug Targets 15:329-336. https://doi.org/10. 2174/1871527315666160202125914

28. Heneka MT, Golenbock DT, Latz E (2015) Innate immunity in Alzheimer's disease. Nat Immunol 16:229-236. https://doi.org/10. 1038/ni.3102

29. Wiatrak B, Kubis-Kubiak A, Piwowar A, Barg E (2020) PC12 cell line: cell types, coating of culture vessels, differentiation and other culture conditions. Cells 9:958. https://doi.org/10.3390/ cells9040958

30. Starr T, Bauler TJ, Malik-Kale P, Steele-Mortimer O (2018) The phorbol 12-myristate-13-acetate differentiation protocol is critical to the interaction of THP-1 macrophages with Salmonella Typhimurium. PLoS One 13:e0193601. https://doi.org/10.1371/ journal.pone. 0193601

31. Lund ME, To J, O'Brien BA, Donnelly S (2016) The choice of phorbol 12-myristate 13-acetate differentiation protocol influences the response of THP-1 macrophages to a pro-inflammatory stimulus. J Immunol Methods 430:64-70. https://doi.org/10.1016/j.jim. 2016.01.012

32. Daigneault M, Preston JA, Marriott HM, Whyte MKB, Dockrell DH (2010) The identification of markers of macrophage differentiation in PMA-stimulated THP-1 cells and monocyte-derived macrophages. PLoS One 5:e8668. https://doi.org/10.1371/journal.pone. 0008668

33. Sheppe AEF, Kummari E, Walker A, Richards A, Hui WW, Lee JH, Mangum L, Borazjani A et al (2018) PGE2 augments inflammasome activation and M1 polarization in macrophages infected with Salmonella Typhimurium and Yersinia enterocolitica. Front Microbiol 9:2447. https://doi.org/10.3389/fmicb.2018.02447

34. Tedesco S, De Majo F, Kim J et al (2018) Convenience versus biological significance: are PMA-differentiated THP-1 cells a reliable substitute for blood-derived macrophages when studying in vitro polarization? Front Pharmacol 9:71. https://doi.org/10. 3389/fphar.2018.00071

35. Park EK, Jung HS, Yang HI, Yoo MC, Kim C, Kim KS (2007) Optimized THP-1 differentiation is required for the detection of responses to weak stimuli. Inflamm Res 56:45-50. https://doi.org/ 10.1007/s00011-007-6115-5

36. Shmueli O, Gdalyahu A, Sorokina K, Nevo E, Avivi A, Reiner O (2001) DCX in PC12 cells: CREB-mediated transcription and neurite outgrowth. Hum Mol Genet 10:1061-1070. https://doi. org $/ 10.1093 / \mathrm{hmg} / 10.10 .1061$

37. Lee Y-W, Stachowiak EK, Birkaya B, Terranova C, Capacchietti M, Claus P, Aletta JM, Stachowiak MK (2013) NGF-induced cell differentiation and gene activation is mediated by integrative nuclear FGFR1 signaling (INFS). PLoS One 8:e68931. https://doi.org/ 10.1371/journal.pone.0068931

38. Grytting VS, Olderbø BP, Holme JA, Samuelsen JT, Solhaug A, Becher R, Bølling AK (2019) Di-n-butyl phthalate modifies PMAinduced macrophage differentiation of THP-1 monocytes via PPAR $\gamma$. Toxicol in Vitro 54:168-177. https://doi.org/10.1016/j. tiv.2018.09.004

39. Moir RD, Lathe R, Tanzi RE (2018) The antimicrobial protection hypothesis of Alzheimer's disease. Alzheimers Dement 14:16021614. https://doi.org/10.1016/j.jalz.2018.06.3040

40. Spitzer P, Condic M, Herrmann M, Oberstein TJ, ScharinMehlmann M, Gilbert DF, Friedrich O, Grömer T et al (2016) Amyloidogenic amyloid- $\beta$-peptide variants induce microbial agglutination and exert antimicrobial activity. Sci Rep 6:32228. https://doi.org/10.1038/srep32228

41. Gosztyla ML, Brothers HM, Robinson SR (2018) Alzheimer's amyloid- $\beta$ is an antimicrobial peptide: a review of the evidence. J Alzheimers Dis 62:1495-1506. https://doi.org/10.3233/JAD171133

42. Welling MM, Nabuurs RJA, van der Weerd L (2015) Potential role of antimicrobial peptides in the early onset of Alzheimer's disease. Alzheimers Dement 11:51-57. https://doi.org/10.1016/j.jalz.2013. 12.020

43. Zhao Y, Lukiw WJ (2015) Microbiome-generated amyloid and potential impact on amyloidogenesis in Alzheimer's disease (AD). J Nat Sci 1:e138

44. Hölttä M, Hansson O, Andreasson U, Hertze J, Minthon L, Nägga K, Andreasen N, Zetterberg $H$ et al (2013) Evaluating amyloid- $\beta$ 
oligomers in cerebrospinal fluid as a biomarker for Alzheimer's disease. PLoS One 8:e66381. https://doi.org/10.1371/journal. pone.0066381

45. Chen C-C, Bates R, Carlson J (2014) Effect of environmental and cultural conditions on medium $\mathrm{pH}$ and explant growth performance of Douglas-fir ( Pseudotsuga menziesii) shoot cultures. F1000Research 3:298. https://doi.org/10.12688/f1000research. 5919.2

46. Ikonomovic MD, Klunk WE, Abrahamson EE, Mathis CA, Price JC, Tsopelas ND, Lopresti BJ, Ziolko S et al (2008) Post-mortem correlates of in vivo PiB-PET amyloid imaging in a typical case of Alzheimer's disease. Brain 131:1630-1645. https://doi.org/10. 1093/brain/awn016

47. Peña F, Ordaz B, Balleza-Tapia H, Bernal-Pedraza R, MárquezRamos A, Carmona-Aparicio L, Giordano M (2010) Betaamyloid protein (25-35) disrupts hippocampal network activity: role of Fyn-kinase. Hippocampus 20:78-96. https://doi.org/10. 1002/hipo.20592

48. Bates KA, Verdile G, Li QX, Ames D, Hudson P, Masters CL, Martins RN (2009) Clearance mechanisms of Alzheimer's amyloid-beta peptide: Implications for therapeutic design and diagnostic tests. Mol Psychiatry 14:469-486. https://doi.org/10.1038/ mp.2008.96

49. Gregory GC, Halliday GM (2005) What is the dominant a $\beta$ species in human brain tissue? A review. Neurotox Res 7:29-41. https:// doi.org/10.1007/BF03033774

50. Patton RL, Kalback WM, Esh CL, Kokjohn TA, van Vickle GD, Luehrs DC, Kuo YM, Lopez J et al (2006) Amyloid- $\beta$ peptide remnants in AN-1792-immunized Alzheimer's disease patients: a biochemical analysis. Am J Pathol 169:1048-1063. https://doi.org/ 10.2353/ajpath.2006.060269

51. Yankner B, Duffy L, Kirschner D (1990) Neurotrophic and neurotoxic effects of amyloid $\beta$ protein: reversal by tachykinin neuropeptides. Science 250:279-282. https://doi.org/10.1126/science. 2218531

52. Cuevas E, Rosas-Hernandez H, Burks SM, Ramirez-Lee MA, Guzman A, Imam SZ, Ali SF, Sarkar S (2019) Amyloid Beta 2535 induces blood-brain barrier disruption in vitro. Metab Brain Dis 34:1365-1374. https://doi.org/10.1007/s11011-019-00447-8

53. Zheng X, Xie Z, Zhu Z, Liu Z, Wang Y, Wei LF, Yang H, Yang $\mathrm{HN}$ et al (2014) Methyllycaconitine alleviates amyloid- $\beta$ peptidesinduced cytotoxicity in SH-SY5Y cells. PLoS One 9:e111536. https://doi.org/10.1371/journal.pone.0111536

54. Luo Y, Sunderland T, Roth GS, Wolozin B (1996) Physiological levels of $\beta$-amyloid peptide promote $\mathrm{PC} 12$ cell proliferation. Neurosci Lett 217:125-128. https://doi.org/10.1016/03043940(96)13087-1

55. López-Toledano MA, Shelanski ML (2004) Neurogenic effect of $\beta$-amyloid peptide in the development of neural stem cells. J Neurosci 24:5439-5444. https://doi.org/10.1523/JNEUROSCI. 0974-04.2004

56. Arevalo MÁ, Roldan PM, Chacón PJ, Rodríguez-Tebar A (2009) Amyloid $\beta$ serves as an NGF-like neurotrophic factor or acts as a NGF antagonist depending on its concentration. J Neurochem 111: 1425-1433. https://doi.org/10.1111/j.1471-4159.2009.06412.x
57. Clark IA, Vissel B (2015) Amyloid $\beta$ : one of three dangerassociated molecules that are secondary inducers of the proinflammatory cytokines that mediate Alzheimer's disease. Br J Pharmacol 172:3714-3727. https://doi.org/10.1111/bph.13181

58. ElAli A, Rivest S (2016) Microglia in Alzheimer's disease: a multifaceted relationship. Brain Behav Immun 55:138-150. https://doi. org/10.1016/j.bbi.2015.07.021

59. Hansen DV, Hanson JE, Sheng M (2018) Microglia in Alzheimer's disease. J Cell Biol 217:459-472. https://doi.org/10.1083/jcb. 201709069

60. Heppner FL, Ransohoff RM, Becher B (2015) Immune attack: the role of inflammation in Alzheimer disease. Nat Rev Neurosci 16: 358-372. https://doi.org/10.1038/nrn3880

61. Foster JA, Rinaman L, Cryan JF (2017) Stress \& the gut-brain axis: regulation by the microbiome. Neurobiol Stress 7:124-136. https:// doi.org/10.1016/J.YNSTR.2017.03.001

62. Lukiw WJ (2016) Bacteroides fragilis lipopolysaccharide and inflammatory signaling in Alzheimer's disease. Front Microbiol 7: 1544. https://doi.org/10.3389/fmicb.2016.01544

63. Sandhu KV, Sherwin E, Schellekens H, Stanton C, Dinan TG, Cryan JF (2017) Feeding the microbiota-gut-brain axis: diet, microbiome, and neuropsychiatry. Transl Res 179:223-244. https://doi.org/10.1016/J.TRSL.2016.10.002

64. Makin S (2018) The amyloid hypothesis on trial. Nature 559:S4 S7. https://doi.org/10.1038/d41586-018-05719-4

65. Paroni G, Bisceglia P, Seripa D (2019) Understanding the amyloid hypothesis in Alzheimer's disease. J Alzheimers Dis 68:493-510. https://doi.org/10.3233/JAD-180802

66. Selkoe DJ, Hardy J (2016) The amyloid hypothesis of Alzheimer's disease at 25 years. EMBO Mol Med 8:595-608. https://doi.org/10. $15252 / \mathrm{emmm} .201606210$

67. Kametani F, Hasegawa M (2018) Reconsideration of amyloid hypothesis and tau hypothesis in Alzheimer's disease. Front Neurosci 12:25. https://doi.org/10.3389/fnins.2018.00025

68. Li Y, Xu P, Shan J, Sun W, Ji X, Chi T, Liu P, Zou L (2020) Interaction between hyperphosphorylated tau and pyroptosis in forskolin and streptozotocin induced AD models. Biomed Pharmacother 121:109618. https://doi.org/10.1016/j.biopha.2019. 109618

69. Yao K, Zhao YF, Zu HB (2019) Melatonin receptor stimulation by agomelatine prevents $A \beta$-induced tau phosphorylation and oxidative damage in PC12 cells. Drug Des Devel Ther 13:387-396. https://doi.org/10.2147/DDDT.S182684

70. Zhou Y, Li C, Li D, Zheng Y, Wang J (2017) IL-5 blocks apoptosis and tau hyperphosphorylation induced by $A \beta 25-35$ peptide in PC12 cells. J Physiol Biochem 73:259-266. https://doi.org/10. 1007/s13105-017-0550-8

71. Cui Z, Tao T, Cheng C, Yang J, Shen Q, Ji Y, Li X, Liu H et al (2010) SSeCKS promote beta-amyloid-induced PC12 cells neurotoxicity by up-regulating tau phosphorylation in Alzheimer's disease. Mol Cell Biochem 340:257-263. https://doi.org/10.1007/ s11010-010-0425-6

Publisher's Note Springer Nature remains neutral with regard to jurisdictional claims in published maps and institutional affiliations. 